\title{
Analysis of Students' Error In Solving Probability Problem: A Case Study In Guangxi
}

\author{
Yuxian Huang ${ }^{1 *}$, Ying Zhou ${ }^{2}$,Yong $\mathbf{L i}^{3}$ \\ 1,2 Deparment of Mathematics and Statistics, Guangxi Normal University, China \\ ${ }^{3}$ Baise National Senior High School, Guangxi, China \\ *1149294058@qq.com
}

\begin{abstract}
Abstrak
Penelitian ini menganalisis jenis dan alasan kesalahan siswa dalam memecahkan probabilitas dan masalah analisis statistik dengan metode penelitian kualitatif. Subjek penelitian berjumlah 20 siswa SMA di SMA di Guangxi, China. Pengumpulan data dilakukan melalui tes diagnostik siswa. Jawaban siswa dianalisis dengan menggunakan analisis O'Connel. Hasil penelitian menunjukkan bahwa proporsi masalah salah paham adalah 48,18\% dengan proporsi terbesar, dan proporsi kesalahan komputasi berikutnya, yaitu 36,36\%. Proporsi kesalahan prosedural paling sedikit, terhitung 15,45\%. Seperti yang kita ketahui bersama, banyak sekali penyebab kesalahan di atas, sehingga guru dapat mencari solusi untuk mengatasi kesalahan tersebut.
\end{abstract}

Kata Kunci: Analisis Kesalahan, Probabilitas, Statistik

\begin{abstract}
This research analyzes the types and reasons of students' mistakes in solving probability and the analysis statistics problems by qualitative research method. The subjects were 20 senior High school students from a senior high school in Guangxi, China. The data were collected through the student diagnostic test. The students' answers were analyzed by using O'Connel's analysis. The results show that the proportion of misunderstood problems is $48.18 \%$ at the largest proportion, and the proportion of computational errors is next, accounting for $36.36 \%$. The proportion of procedural errors is the least, accounting for $15.45 \%$. As we all know, there are many reasons for the above mistakes. so teachers can find some solutions to overcome these mistakes.
\end{abstract}

Keywords: Analysis of Error, Probability, Statistics

Received: Desember 21, 2020 / Accepted: January 9, 2021/ Published Online: January 28, 2021

\section{INTRODUCTION}

Mathematical problem solving ability refers to students' ability to analyze conditions, plan solutions, self-monitoring and evaluation, use various forms of representation to seek relationships and laws, and test the results (Nuha, 2014; Rohaeti, Nurjaman, Sari, Bernard, \& Hidayat, 2019; Tezer \& Karasel, 2010; Zulfah, Astuti, Surya, Marta, \& Wijaya, 2020). Mathematical problem-solving ability plays an indispensable role in the process of mathematical exploration, discovery and innovation (Zhang, Zhou, \& Wijaya, 2020). In 2017, 
The Ministry of education of the people's Republic of China issued The Mathematics Curriculum Standard for Senior High Schools (Cunhua, Ying, Qunzhuang, \& Wijaya, 2019). The news curriculum clearly defined mathematics as abstract and logical, the ultimate goal of cultivating abstract mathematical literacy (Wijaya, Ying, Chotimah, et al., 2020), logical reasoning literacy (Hidayat, Wahyudin, \& Prabawanto, 2018), mathematical modeling literacy (Habibi, Yusop, \& Razak, 2020), intuitive imagination literacy, mathematical operation literacy and data analysis literacy points to the improvement of students' mathematical problem-solving ability (Hidayat \& Sariningsih, 2018), which pushes the students' mathematical problem-solving ability to a new height.

In short, the ability to solve mathematical problems plays an important role. However, Chinese senior three students always make many mistakes in solving mathematical problems, especially in solving probability and statistics problems, which also means that students have great difficulties in solving probability and statistics problems. Through relevant research, we can see that the problems of probability and statistics often need reading materials. These materials embed mathematical factors in certain situations and interweave words, charts and numbers together. If students without specific mathematical reading ability, it is difficult for them to understand the problem's meaning. Besides, many abstract solutions and concepts are involved in probability and statistics problems, so it is complicated for students to understand these methods and concepts in the learning process and use them to solve problems. Probability and statistics problems will involve many complex data, which makes students easy to make calculation errors.

Probability and statistics is a mathematical subject that studies the quantity law of random phenomena, includes how to effectively collect, organize and analyze the relevant data, and make inferences or predictions on the problems investigated (Aditya, Wijaya, Dewi, \& Zulfah, 2020; Wiriyaudomsatean \& Thinwiangthong, 2019). With the rapid development of big data information age, data has penetrated all aspects of people's lives (Aixia, Ying, \& Wijaya, 2020). People need to mine valuable information from many data and make correct decisions based on the information. Therefore, having basic statistical literacy has become the consensus of people in the era of big data (Huang, 2018; Retnawati \& Wulandari, 2019). Besides, probability and statistics also have important educational value. Learning probability helps cultivate students' critical thinking, enhance students' understanding of mathematics, and help students understand the relationship between mathematics and real-life and other subjects (Gasser, 2019; Morsanyi, Primi, Chiesi, \& Handley, 2009; Tan, 2012). Studying 
probability is conducive to the cultivation of students' mathematical thinking, the formation of students' critical thinking, the understanding of mathematics, the enhancement of students' ability to experiment and the cultivation of their interest in mathematics, and the realization of the connection between mathematics and real life as well as other disciplines (Bernard \& Chotimah, 2018; Wijaya, Ying, \& Purnama, 2020; Wijaya, Zulfah, et al., 2020).

The learning of probability and statistics is very important, but students still face many learning probability and statistics. By analyzing students' mistakes, we can know what difficulties students have. However, at present, there is little research on Chinese students' probability and statistical errors, so in order to help Chinese teachers find the source of errors, suit the remedy to the case, guide students to identify errors, think about the causes of errors, and correct the mistakes that have been made. To achieve the purpose of "preventing errors from appearing again" and ultimately improving students' learning quality. This study analyzes the students' s in solving probability and statistics problems.

\section{METHOD}

This study uses case study research with qualitative methods. The research subjects were 20 senior third-grade students from a high school in the city of Guangxi, China. And the phenomenon under study is students' difficulty in solving the probability and statistics problem using O'Connel's difficulty analysis procedure. O'Connel divided students' errors into four categories, including misunderstandings, conceptual errors, procedural errors, and computational error. The error of understanding the text is an error that is caused by misunderstanding the problem. A conceptual error is involving a basic concept of probability theory. Procedural errors are errors arising from using incorrect formulas or strategies to solve problems. Computational error is related to calculation.

The study steps are as follows: first, 20 students were given four test questions of probability and statistical (see Table 1), and each research subject will answer the question within the specified time and write a detailed solution process. The researcher then uses the qualitative research method to analyze the students' answers by using O'Connell's analysis and then uses the quantitative research method to determine the percentage of different types of s. 
Table 1. Question Items of the Research

\section{Question1:}

At the beginning of 2020, affected by the NCP, in order to implement the Ministry of Education's spirit of "suspension of classes but non-stop of teaching", during the period of school extension, an online simulation examination was held in a city, and 100 students were selected and divided into groups according to their mathematics scores (scores between 0 and 140): $[0,20),[20,40),[40,60),[60,80),[80,100)$, $[100,120),[120,140)$. The following frequency histogram is obtained.

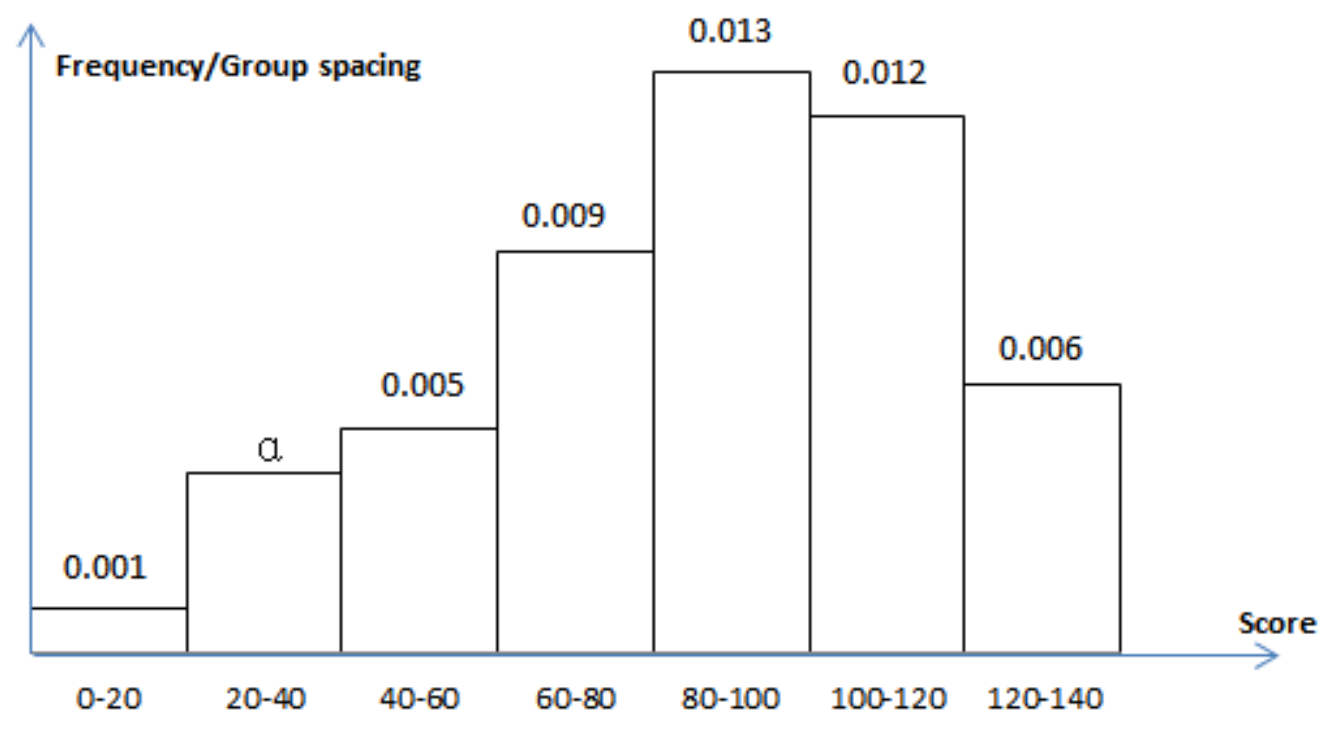

Note: probability is estimated by frequency.

(1)Calculate the value of real number $\alpha$, and estimate the average value of the 100 students' mathematics scores (represented by the midpoint of the same interval)

(2)In order to further better grasp the students' learning situation, three students with mathematics scores in the range of $[0,20),[20,40)$ are randomly selected for telephone interview analysis. Please calculate the probability that the three students selected do not belong to the same group.

\section{Question2:}

The chessboard is marked with $0,1,2 \ldots \ldots 100$, players flip unbiased coins to go checkers, if the front is thrown, the chess piece will jump forward one stop, if the reverse side is thrown, the chess piece will jump forward two stops. Until the 99th or 100th stop, the game will end. Let the probability of the chessman in the nth station be $P_{n}$.

(1) When the game begins, toss the uniform coin three times, and then find the distribution column and mathematical expectation of the sum of the number of steps taken by the chess player. 


\section{Question3:}

$5 \mathrm{G}$ network is the abbreviation of the fifth-generation mobile communication network, and it is one of the most representative technologies in the new round of scientific and technological revolution. Since the beginning of 2020, China's 5G network is spreading in a large area. To understand the citizens' satisfaction with the quality of $5 \mathrm{G}$ network service in a city, an investigation institution conducts an investigation. A questionnaire survey was conducted among 200 people who used 5g mobile phones, and the 200 people were divided into the following six groups according to their satisfaction score (Full Score: 100 points): $[40,50),[50,60),[60,70) \ldots,[90,100)$, and the statistical results.

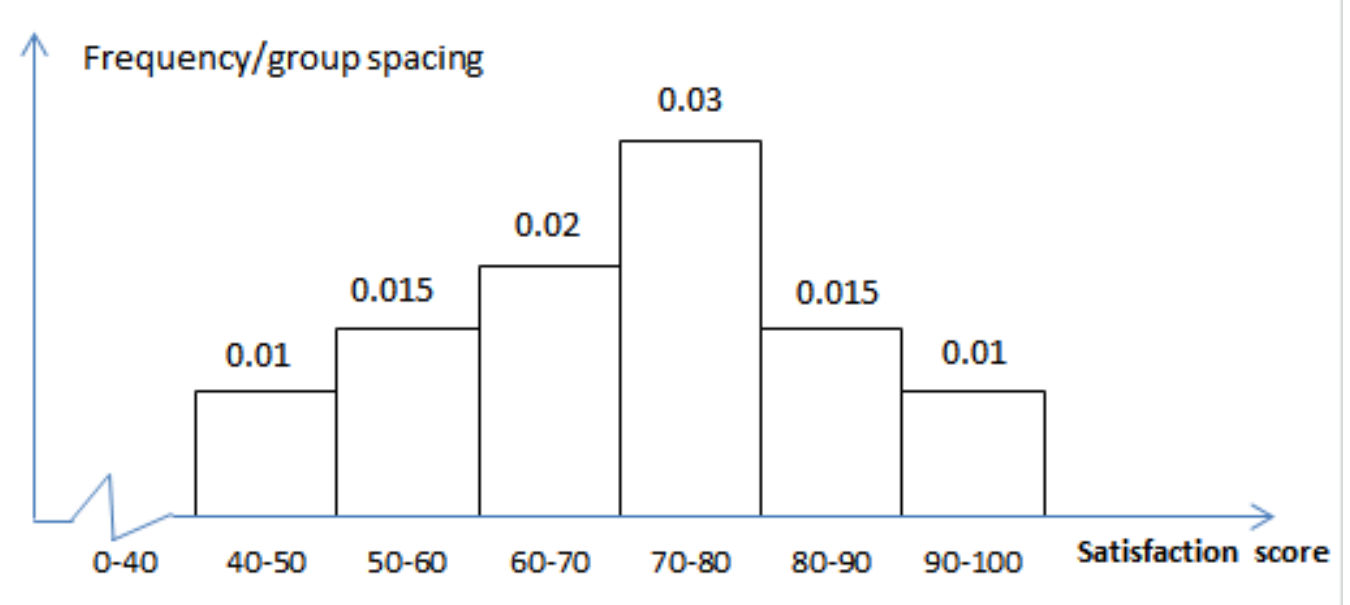

(1) According to the histogram, the satisfaction score $\mathrm{z}$ (unit: score) of 5G mobile phone users in A city follows the normal distribution $N\left(\mu, \sigma^{2}\right)$, which $\mu$ is approximate to the average number of samples $\bar{x}$, and $\delta$ approximate to the standard deviation of the sample standard deviation of samples is $\mathrm{s}=14.31$. If there are only $200005 \mathrm{G}$ mobile phone users in A city. Please estimated the satisfaction score of these $5 \mathrm{G}$ mobile phone users is in the range of $(56.19,99.12]$ (represented by the median value of the interval)

(2) (a) To participate in the survey of 5G mobile phone users, the survey organization held a lucky draw, with each person having a maximum of 10 rounds of lucky draw. Each round of lottery activities was independent of each other, and the winning rate was $1 / 2$. In each round of lottery, if you win the prize, the prize is 100 yuan, and continued to participate in the next round of lottery; if not, the lottery ended, and now Xiao Wang participated in the lottery activity, asking the probability that Xiao Wang to win 900 yuan of telephone charges. (the result is accurate to 0.01).

(b) Find the expected value of the total telephone charge X obtained by Xiao Wang (the result is accurate to 0.01 )

\section{Question4:}

To give full play to the unique educational value of sports in the era of core literacy, 
more and more middle schools have incorporated some sports items into students' compulsory courses. A middle school plans to offer swimming courses in the first grade of senior high school. To understand the students the school conduct an investigation, the study found that the proportion of boys and girls interested in swimming is $3: 2$, and 15 boys are not interested in swimming, accounting for $1 / 3$ of the number of boys.

question:(1) Complete the $2 \times 2$ contingency and answer if you are $99 \%$ sure that "gender is related to interest in swimming."

(2) From the students interested in swimming, select 5 students based on the stratified sampling method of boys and girls, and then select 3 people from them. Recording the number of girls extracted as $\mathrm{X}$ and calculating probability distribution and X's mathematical expected value.

\begin{tabular}{|c|c|c|c|c|c|}
\hline \multicolumn{6}{|c|}{$K^{2}=\frac{n(a d-b c)^{2}}{(a+b)(c+d)(a+c)(b+d)} n=a+b+c+d$} \\
\hline$P\left(K^{2} \geq k_{0}\right)$ & 0.150 & 0.100 & 0.050 & 0.025 & 0.010 \\
\hline$k_{0}$ & 2.072 & 2.706 & 3.841 & 5.024 & 6.635 \\
\hline
\end{tabular}

\section{RESULTS}

According to O'Connell's error analysis procedure (Arum, Kusmayadi, \& Pramudya, 2018; Legesse, Luneta, \& Ejigu, 2020), the amount and percentage of three types of errors were counted (see Table 2). Based on the Table 2 , the information is obtained that Twenty students made a total of 110 mistakes in answering four probability and statistics questions. Among them, there were 53 misunderstanding of problem, accounting for $48.18 \%$, and procedural errors were 17, accounting for $15.45 \%$, and computational errors were 40, accounting for $36.36 \%$. This shows that students have great difficulties in understanding and calculating problems when solving probability and statistics problems. Next, the types of errors students encounter in solving probability and statistics problems are explained in Table $\underline{2}$.

Table 2. Percentage of Types of Student Difficulties in 4 Question Items

\begin{tabular}{llllllc}
\hline \multicolumn{1}{c}{$\begin{array}{c}\text { Type of } \\
\text { Difficulty }\end{array}$} & $\begin{array}{c}\text { Problem } \\
\mathbf{1}\end{array}$ & $\begin{array}{c}\text { Problem } \\
\mathbf{2}\end{array}$ & $\begin{array}{c}\text { Problem } \\
\mathbf{3}\end{array}$ & $\begin{array}{c}\text { Problem } \\
\mathbf{4}\end{array}$ & $\begin{array}{c}\text { Number of } \\
\text { Difficulties }\end{array}$ & $\begin{array}{c}\text { Percentage } \\
(\boldsymbol{\%})\end{array}$ \\
\hline $\begin{array}{l}\text { Misunderstandin } \\
\text { g of Problem }\end{array}$ & 1 & 9 & 40 & 3 & 53 & $48.18 \%$ \\
\begin{tabular}{l} 
Procedural errors \\
\hline
\end{tabular} & 1 & 0 & 8 & 8 & 17 & $15.45 \%$ \\
\hline
\end{tabular}




\begin{tabular}{llllllc}
\hline \multicolumn{1}{c}{$\begin{array}{c}\text { Type of } \\
\text { Difficulty }\end{array}$} & $\begin{array}{c}\text { Problem } \\
\mathbf{1}\end{array}$ & $\begin{array}{c}\text { Problem } \\
\mathbf{2}\end{array}$ & $\begin{array}{c}\text { Problem } \\
\mathbf{3}\end{array}$ & $\begin{array}{c}\text { Problem } \\
\mathbf{4}\end{array}$ & $\begin{array}{c}\text { Number of } \\
\text { Difficulties }\end{array}$ & $\begin{array}{c}\text { Percentage } \\
(\boldsymbol{\%})\end{array}$ \\
\hline $\begin{array}{l}\text { Computationaler } \\
\text { ror s }\end{array}$ & 15 & 2 & 8 & 15 & 40 & $36.36 \%$ \\
\begin{tabular}{l} 
Total \\
\hline
\end{tabular} & 17 & 11 & 56 & 26 & 110 & $100.00 \%$ \\
\hline
\end{tabular}

\section{Misunderstanding of Problem}

Misunderstanding of problem refers to students cannot understand the information given by the questions or present the information given by the questions, or students do not know what the questions are asking for, which eventually leads to the students' inability to answer questions or give an irrelevant answer (Salido \& Dasari, 2019). An example of students' $\mathrm{s}$ in solving a probability and statistics problem related to this category of difficulty is shown in Figure 1.

According to Figure 1 from the answers of student 18, it can be seen that although student 18 knows what the question is and the ratio of boys and girls given by the question, student 18 does not understand the idea of the question information "extract 3 more students from the question, and record the number of girls extracted is X". Therefore, when solving the question, student 18 lists the possible events involving four or five people, which is more than 3 people and does not meet the requirements of the question. From the answer of student 13, we can see that student 13 tried his best to answer a question (1), but failed to answer question (2), which means that student 13 is seriously answering the question, but can't answer it because he does not understand the information of the question. From the above analysis, we can see that students have difficulty understanding the known information of probability and statistics problems.

\section{S13:}

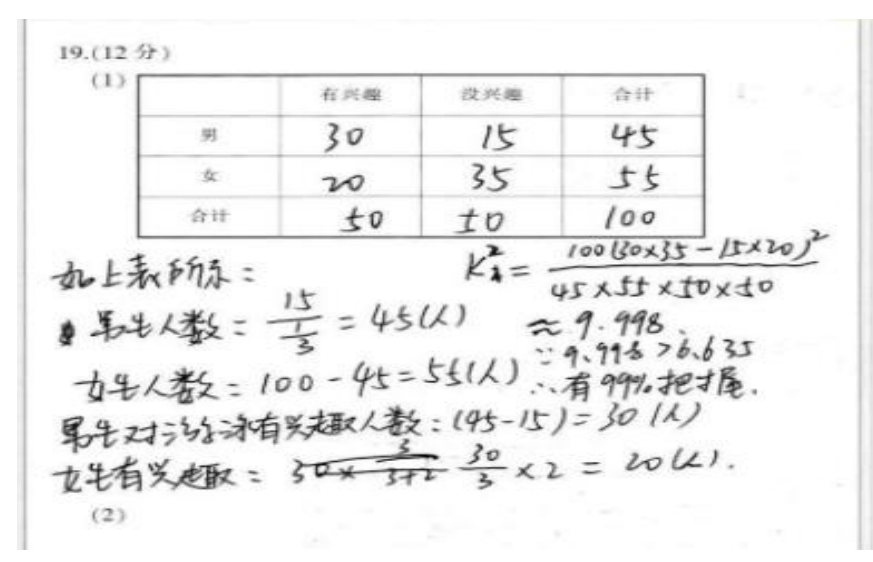


S18:

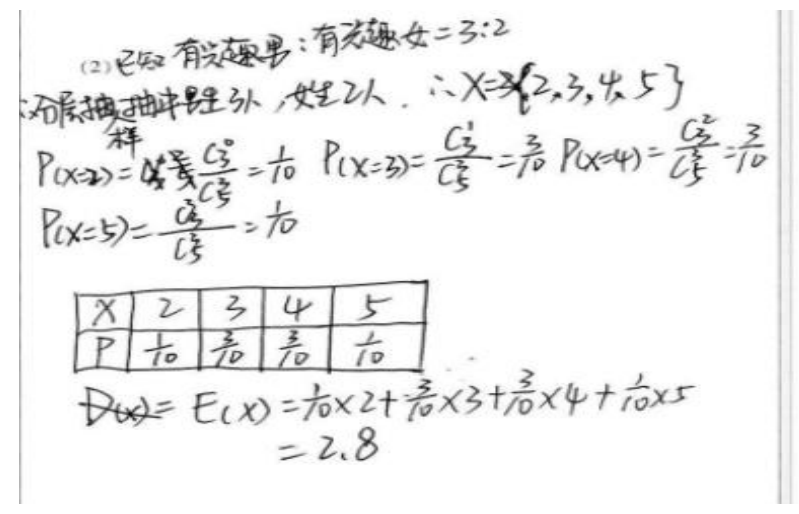

Student answer: Have known interested male: interested female $=$ $3: 2$;

In stratified sampling, 3 boys and 2 girls were selected;

$$
\begin{aligned}
& \text { So } X=\{2,3,4,5\} \\
& P(X=2)=\frac{C_{3}^{0}}{C_{5}^{3}}=\frac{1}{10} \\
& P(X=3)=\frac{C_{3}^{1}}{C_{5}^{3}}=\frac{3}{10} \\
& P(X=4)=\frac{C_{3}^{2}}{C_{5}^{3}}=\frac{3}{10} \\
& P(X=4)=\frac{C_{3}^{3}}{C_{5}^{3}}=\frac{1}{10}
\end{aligned}
$$

\begin{tabular}{|l|l|l|l|l|}
\hline $\mathrm{X}$ & 2 & 3 & 4 & 5 \\
\hline $\mathrm{p}$ & $\frac{1}{10}$ & $\frac{3}{10}$ & $\frac{3}{10}$ & $\frac{1}{10}$ \\
\hline
\end{tabular}

Figure 1. Example of the misunderstanding of problem

\section{Procedural Errors}

Procedural errors refer to students can't use correct formulas or strategies to solve problems, although they already know what information is given and what questions to ask. An example of students' $\mathrm{s}$ in solving a probability and statistics problem related to this category of difficulty is shown in Figure 2.

Based on Figure 2 we can see that student 3 already knows that Xiao Wang can draw 10 times if he win 900 yuan. However, when student 3 calculating the probability of Xiao Wang winning 900 yuan, he only multiplies the probability of winning the first nine times and does not multiply the probability of losing the tenth prize. Student 3 does not use the correct strategy to solve the problem. We also can see that students 7 and 14 do not understand the 
preconditions for binomial distribution, so they did not answer correctly. All these errors indicate that students have great difficulties in solving probability and statistics problems with correct strategies.

S3:

(2) 由题意得: 共抽10次。

小王获得 900 无话费, 即连中 9 次、

相到: $\left(\frac{1}{2}\right)^{9}=\frac{1}{512}$

S7:

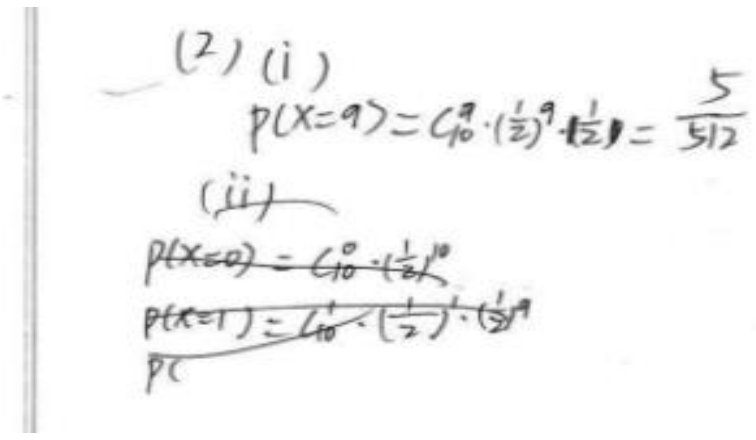

S14:

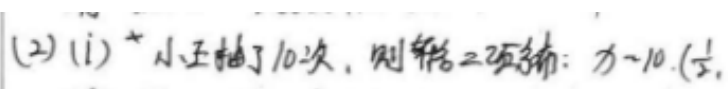
$P(x=11)=C_{10}\left(\frac{1}{2}\right)^{9}\left(1-\frac{1}{2}\right) \geq$
Student answer: According to the information of the problem, we can know that: A total of 10 times were drawn, and Xiao Wang won 900 yuan, so Xiao Wang hit the prize 9 times.

So $P=\left(\frac{1}{2}\right)^{9}=\frac{1}{512}$

\section{Student answer:}

$P=(X=9)=C_{10}^{9}\left(\frac{1}{2}\right)^{9}\left(\frac{1}{2}\right)=\frac{5}{512}$

\section{Student answer:}

A total of 10 times were drawn, and it is binomial distribution $X \sim 10\left(\frac{1}{2}, 10\right)$

Figure 2. Example of procedural's

\section{Computational}

Calculation refers to the phenomenon that students have been able to choose the correct formula to solve the problem, but there are operational errors or can not remember the formula clearly. The following examples are explained in detail. 
It can be seen from Figure 3 that student 8 and student 20 have been able to list the correct formula for calculating the mean value according to the information given in the title. However, neither student 8 nor student 20 can work out the correct answer. Student 8 may be afraid to continue to calculate when he saw a string of numbers, while student 20 may be due to careless calculation in the process of calculation. The above examples show that students have difficulty in solving probability and statistics problems.

\section{Student answer:}

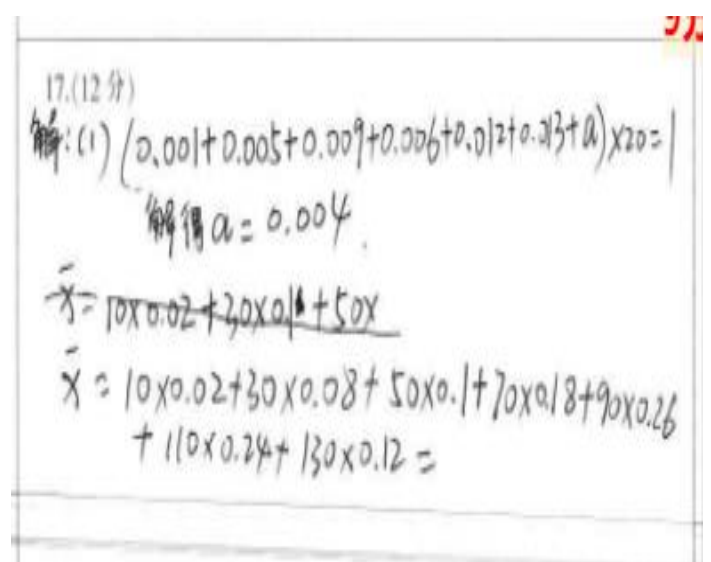

$$
\begin{aligned}
& (0.001+0.003+0.009+0.006+0.01+0.013) \times 20=1 \\
& \alpha=0.004 \\
& \bar{x}=10 \times 0.02+30 \times 0.08+50 \times 0.1+70 \times 0.018 \\
& +90 \times 0.26+110 \times 0.24+130 \times 0.12=
\end{aligned}
$$

S8:

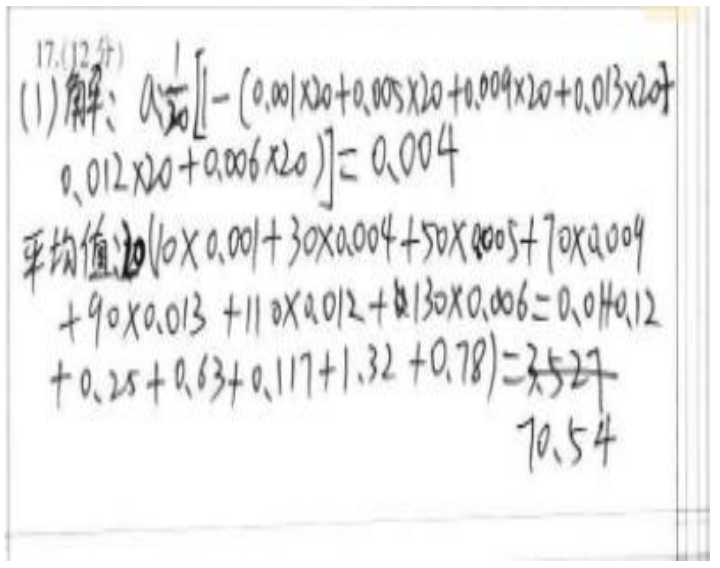

\section{Student answer :}

$$
\begin{aligned}
& \alpha=\frac{1}{20}[1-(0.001 \times 20+0.005 \times 20+0.009 \times 20 \\
& +0.013 \times 20+0.012 \times 20+0.006 \times 20)]=0.004 \\
& \bar{x}=20 \times(10 \times 0.001+30 \times 0.004+50 \times 0.005+70 \times 0.004 \\
& +90 \times 0.013+110 \times 0.012+130 \times 0.006) \\
& =0.01+0.12+0.25+0.63+0.117+1.32+0.78=70.54
\end{aligned}
$$

S20:

Figure 3. Example of computational 


\section{DISCUSSION}

Based on the above research results, this part will discuss the reasons why students make the above three kinds of mistakes in solving probability and statistics problems, and give suggestions to reduce the mistakes. Among the three types of errors, misunderstanding of problem accounts for the largest proportion, which means students do not understand the questions or questions (Ngirishi \& Bansilal, 2019). There are several reasons as follows. The first reason is that probability and statistics problems will involve some abstract concepts, which are difficult for students to understand. The second reason is that probability and statistics problems often need reading materials. These materials embed mathematical factors in certain situations and intertwine words, charts and numbers. Suppose students don't have certain mathematics reading ability and life experience. In that case, it will be difficult to identify the useful information in the questions and understand the questions' overall meaning, which will eventually lead to students not understanding the questions. Another reason is that the question's logic is very difficult to understand, leading to students not understanding the question.

To minimize the students' misunderstanding errors, teachers should teach students the skills to read questions, in other words, teacher should lead the students to read the information of the problem, find the useful information in the problem, and express the relationship of the useful information in the way of drawing or other ways. At the same time, let the students try to explain abstract sentences in the problem. Besides, to improve students' ability to read mathematical problems, teachers can cultivate students' habit of reading mathematics textbooks and extracurricular reading.

Among the three types of errors, computational errors accounts for second place. There are several reasons are as follows: the first reason is that students don't have the habit of reexamination. The second reason is the students' anxious psychology. When the probability and statistics topics involve some complicated numbers, the students are often too anxious and unstable to make calculation errors. The third reason is that students do not master the operation program. In other words, probability and statistics problems involve some abstract operation formulas. Although students know to use this formula to calculate, they do not know the specific operation program. In order to reduce the students' mistakes, we can take the following actions. Teachers can ask the students to write down the detailed calculation steps, and remind the students to check whether each calculation step is correct after finishing the homework . 
In these three types of problems, the proportion of procedural errors is the smallest. The reason for procedural errors is that probability theory and statistics involve a lot of abstract knowledge. In the process of learning, students do not understand these knowledge, and easy to confuse this knowledge, so students do not know how to apply the knowledge or methods to the new problem situation. Research results also confirm this reason Setiawan, Hapizah, \& Hiltrimartin (2018). Based on the above reasons, in daily teaching, teachers should connect new knowledge with students' real life and old knowledge, which help students understand abstract new knowledge, and use mind map to help students sort out easily confused knowledge.

\section{CONCLUSION}

Based on the above research, the following conclusions are drawn. Through the analysis of the specific types of students' solving probability and statistics problems, we can find that 20 students have made 110 mistakes in total. Among the three types of errors, misunderstanding of problem account for the largest proportion, which is due to three reasons: firstly, it is difficult for students to understand the abstract concepts involved in probability and statistics problems; secondly, due to students' weak mathematical reading ability or less life experience, it is difficult for students to extract useful information from complex problem or understand the overall meaning of the problem; thirdly, the problem is too logical for students to clarify the meaning of the problem. The proportion of computational error at the second place. The reasons are: firstly, students do not have the habit of review; secondly, students' anxious psychology leads to calculation errors; thirdly, students do not master the operation program. The proportion of procedural error type is the smallest, and the reason for this type of error is that probability and statistics problems involve a lot of abstract knowledge, and students do not understand these knowledge in the learning process, so it is easy to confuse this knowledge. Based on the above research, to reduce students' difficulties or errors in solving probability and statistics problems, teachers can do the following things: 1) teaching the students the skills to read questions and cultivating the students' habit of mathematics textbooks and extracurricular reading. 2) asking the students to write down the detailed calculation steps and remind them to check whether each calculation step is correct after finishing the homework. 3 ) in daily teaching, teachers should connect new knowledge with students' real life and old knowledge, which 
help students understand abstract new knowledge, and use mind map to help students sort out easily confused knowledge.

\section{REFERENCES}

Aditya, P., Wijaya, T. T., Dewi, S. N., \& Zulfah, Z. (2020). Analisis buku siswa matematika SMA dari Indonesia dan China pada materi peluang dan statistik. Jurnal Cendekia: Jurnal Pendidikan Matematika, 4(2), 813-822.

Aixia, W., Ying, Z., \& Wijaya, T. T. (2020). The current situation and prospect of study quality evaluation research in china in the last 10 years. EDUKATIF: Jurnal Ilmu Pendidikan, 2(1), 101-112.

Arum, D. P., Kusmayadi, T. A., \& Pramudya, I. (2018). Students' difficulties in probabilistic problem-solving. Journal of Physics: Conference Series, 983(1). https://doi.org/10.1088/1742-6596/983/1/012098

Bernard, M., \& Chotimah, S. (2018). Improve student mathematical reasoning ability with open-ended approach using VBA for powerpoint. AIP Conference Proceedings, 2014(September). https://doi.org/10.1063/1.5054417

Cunhua, L., Ying, Z., Qunzhuang, O., \& Wijaya, T. T. (2019). Mathematics course design based on six questions cognitive theory using hawgent dynamic mathematic. Journal On Education, 02(01), 36-44.

Gasser, B. (2019). What happened to the participants of the math olympiad 1971? A multiplecase study concerning the occupational success of the winning team from hungary, math olympiad-occupational success. Journal of Intelligence, 7(1). https://doi.org/10.3390/jintelligence7010009

Habibi, A., Yusop, F. D., \& Razak, R. A. (2020). The role of TPACK in affecting pre-service language teachers' ICT integration during teaching practices: Indonesian context. Education and Information Technologies, 25(3), 1929-1949. https://doi.org/10.1007/s10639-019-10040-2

Hidayat, W., Wahyudin, W., \& Prabawanto, S. (2018). Improving students' creative mathematical reasoning ability students through adversity quotient and argument driven inquiry learning. Journal of Physics: Conference Series, 948(1). https://doi.org/https://doi.org/10.1088/1742-6596/948/1/012005

Hidayat, W, \& Sariningsih, R. (2018). Kemampuan Pemecahan Masalah Matematis dan Adversity Quotient Siswa SMP Melalui Pembelajaran Open Ended. JNPM (Jurnal Nasional Pendidikan Matematika), 2(1), 109. https://doi.org/10.33603/jnpm.v2i1.1027

Huang, Z. (2018). Theoretical analysis of TPACK knowledge structure of mathematics teachers based on T-TPACK mode. Kuram ve Uygulamada Egitim Bilimleri, 18(5), 2044-2053. https://doi.org/10.12738/estp.2018.5.103 
Legesse, M., Luneta, K., \& Ejigu, T. (2020). Analyzing the effects of mathematical discoursebased instruction on eleventh-grade students' procedural and conceptual understanding of probability and statistics. Studies in Educational Evaluation, 67(July), 100918. https://doi.org/10.1016/j.stueduc.2020.100918

Morsanyi, K., Primi, C., Chiesi, F., \& Handley, S. (2009). The effects and side-effects of statistics education: Psychology students' (mis-)conceptions of probability. Contemporary Educational Psychology, 34(3), 210-220. https://doi.org/10.1016/j.cedpsych.2009.05.001

Ngirishi, H., \& Bansilal, S. (2019). An exploration of high school learners' understanding of geometric concepts. Problems of Education in the 21st Century, 77(1), 82-96. https://doi.org/10.33225/PEC/19.77.82

Nuha, M. A. (2014). Analisis Kemampuan Pemecahan Masalah Geometri dan Karakter Siswa SMP Kelas VIII Melalui Pembelajaran Model 4K. Kreano: Jurnal Matematika KreatifInovatif, 5(2), 188-194. https://doi.org/10.15294/kreano.v5i2.4549

Retnawati, H., \& Wulandari, N. F. (2019). The development of students' mathematical literacy proficiency. Problems of Education in the 21st Century, 77(4), 502-514. https://doi.org/10.33225/pec/19.77.502

Rohaeti, E. E., Nurjaman, A., Sari, I. P., Bernard, M., \& Hidayat, W. (2019). Developing didactic design in triangle and rectangular toward students mathematical creative thinking through Visual Basic for PowerPoint. Journal of Physics: Conference Series, 1157(4). https://doi.org/https://doi.org/10.1088/1742-6596/1157/4/042068

Salido, A., \& Dasari, D. (2019). Students' errors in solving probability problems viewed by learning style. Journal of Physics: Conference Series, 1211(1). https://doi.org/10.1088/1742-6596/1211/1/012067

Setiawan, Y., Hapizah H, and Hiltrimartin C. (2018). Kesalahan siswa dalam menyelesaikan soal olimpiade SMP konten aljabar. Jurnal Riset Pendidkan Matematika, 5 (2). 233-234.

Tan, C. K. (2012). Effects of the application of graphing calculator on students' probability achievement. Computers and Education, 58(4), 1117-1126. https://doi.org/10.1016/j.compedu.2011.11.023

Tezer, M., \& Karasel, N. (2010). Attitudes of primary school 2nd and 3rd grade students towards mathematics course. Procedia - Social and Behavioral Sciences, 2(2), 58085812. https://doi.org/10.1016/j.sbspro.2010.03.947

Wijaya, T. T., Ying, Z., Chotimah, S., Bernard, M., Zulfah, \& Astuti. (2020). Hawgent dynamic mathematic software as mathematics learning media for teaching quadratic functions. Journal of Physics: Conference Series, 1592(1). https://doi.org/10.1088/1742$6596 / 1592 / 1 / 012079$

Wijaya, T. T., Ying, Z., \& Purnama, A. (2020). Using Hawgent dynamic mathematics software in teaching trigonometry. International Journal of Emerging Technologies in Learning, 15(10). https://doi.org/10.3991/ijet.v15i10.13099 
Wijaya, T. T., Zulfah, Z., Hidayat, A., Akbar, P., Arianti, W., \& Asyura, I. (2020). Using VBA for microsoft excel based on 6-questions cognitive theory in teaching fraction. Journal of Physics: Conference Series, 1657(1), 012078. https://doi.org/10.1088/1742$6596 / 1657 / 1 / 012078$

Wiriyaudomsatean, T., \& Thinwiangthong, S. (2019). Students' Words in Mathematical Communication in Classroom Using Lesson Study and Open Approach. Journal of Physics: Conference Series, 1340(1). https://doi.org/10.1088/1742-6596/1340/1/012090

Zhang, L., Zhou, Y., \& Wijaya, T. T. (2020). Hawgent dynamic mathematics software to improve problem-solving ability in teaching triangles. Journal of Physics: Conference Series, 1663(1). https://doi.org/10.1088/1742-6596/1663/1/012069

Zulfah, Astuti, Surya, Y. F., Marta, R., \& Wijaya, T. T. (2020). Measurement of mathematics problems solving ability using problem based mathematics question. Journal of Physics: Conference Series, 1613(1). https://doi.org/10.1088/1742-6596/1613/1/012026 